\title{
Daya Terima Panelis dan Karakterisasi Selai Kulit Pisang Kepok dengan Penambahan Pisang Ambon
}

\author{
Panelists Acceptance and Characterization of Kepok Banana Peels Jam with The \\ Addition of Ambon Banana \\ SITI MUNASARI ${ }^{*}$, DWI SANDRI ${ }^{1}$, JEFRIADI $^{2}$ \\ ${ }^{1}$ Jurusan Teknologi Industri Pertanian Politeknik Negeri Tanah Laut, Jl. A. Yani, Km.6, \\ Desa Panggung, Kec. Pelaihari, Kab. Tanah Laut, Kalimantan Selatan 70815, Indonesia \\ ${ }^{2}$ Program Studi Teknik Kimia Fakultas Teknik Universitas Lambung Mangkurat, Jl. A. \\ Yani, Km.36, Banjarbaru, Kalimantan Selatan 70714, Indonesia \\ "Email: munasarist@gmail.com
}

\begin{abstract}
Kepok banana peels (Musa paradisiaca forma typical) is a by product of kepok banana used by the food industry. The current kepok banana peels has not been utilized productively, when kepok banana peels still have nutrient content and pectin which can be processed into food products namely jams. To improve the quality of jam kepok banana peels conducted addition of ambon banana. The purpose of this research is to know the effect of adding ambon banana to the level of jam preference, to get the best formulation based on panelist acceptance, and to measure the jam characterization resulting from all treatments. Stages of making jam was by making the banana peel and banana porridge pulp then cooked with sugar and citric acid. The acceptance analysis of jam was done by the favorite test (hedonic) then the data were analyzed by ANOVA and DMRT test. Characteristic of jam were done by water content test and smear test. Addition of ambon banana has a significant effect on the taste of jam, the best jam formulation based on panelist acceptability was on 50\%: 50\% treatment of banana peel with banana pulp of ambon. Characterization of jam resulted from all treatments have water content ranged from $29.71-35.06 \%$ and the topicality ranged from 9 to $11.6 \mathrm{~cm}$.
\end{abstract}

Keywords: Kepok Banans Peels, ambon bananas, jam.

\begin{abstract}
ABSTRAK
Kulit pisang kepok (Musa paradisiaca forma typical) merupakan hasil samping dari pisang kepok yang digunakan oleh industri pangan. Saat ini kulit pisang kepok belum banyak dimanfaatkan secara produktif, padahal kulit pisang kepok masih memiliki kandungan gizi dan pektin yang dapat diolah menjadi produk pangan yaitu selai. Untuk meningkatkan mutu selai kulit pisang kepok dilakukan penambahan pisang ambon. Tujuan dari penelitian ini adalah mengetahui pengaruh penambahan pisang ambon terhadap tingkat kesukaan selai, mendapatkan formulasi terbaik berdasarkan daya terima panelis dan mengukur karakterisasi selai yang dihasilkan dari semua perlakuan. Tahapan pembuatan selai yaitu dengan membuat bubur kulit pisang kepok dan bubur pisang ambon kemudian dimasak dengan gula dan asam sitrat. Analisis daya terima selai dilakukan dengan uji tingkat kesukaan (hedonik) kemudian data dianalisis dengan uji ANOVA dan DMRT. Karakteristik selai dilakukan dengan uji kadar air dan uji daya oles. Penambahan pisang ambon berpengaruh nyata terhadap rasa selai, formulasi selai terbaik berdasarkan daya terima panelis adalah pada perlakuan 50\%:50\% bubur kulit pisang
\end{abstract}


kepok dengan bubur pisang ambon. Karakterisasi selai yang dihasilkan dari semua perlakuan mempunyai kadar air berkisar $29,71-35,06 \%$ dan daya oles berkisar antara 9 $-11,6 \mathrm{~cm}$.

Kata kunci : kulit pisang kepok, pisang ambon, selai

\section{PENDAHULUAN}

Tanaman pisang merupakan salah satu komoditas unggulan Provinsi Kalimantan Selatan khususnya Kabupaten Tanah Laut dengan produksi pisang pada tahun 2016 sebesar 209.2 Ton (BPS Kabupaten Tanah Laut, 2016). Salah satu jenis pisang yang banyak dibudidayakan dan dimanfaatkan adalah pisang kepok, yang tergolong jenis pisang olah. Pisang kepok banyak digunakan oleh industri makanan seperti industri keripik pisang, pedagang gorengan dan lain-lain. Pemanfaatan pisang kepok yang cukup besar tersebut, menghasilkan limbah kulit pisang yang belum banyak dimanfaatkan secara produktif, dimana kulit pisang kepok masih memilki kandungan gizi seperti karbohidrat, lemak, serat, air dan pektin (Sutriono dkk., 2016). Karakteristik kulit pisang kepok yang tebal dan memiliki kandungan pektin memberikan peluang pemanfaatan limbah ini menjadi bahan olahan produk pangan lain yaitu selai.

Selai merupakan produk awetan yang dibuat dengan cara memasak hancuran buah yang dicampur gula baik ditambah air atau tanpa penambahan air dan bahan tambahan lainnya. Berdasarkan uji pendahuluan, Selai yang terbuat dari kulit pisang kepok masih mempunyai rasa yang sedikit sepat. Oleh karena itu, untuk meningkatkan mutu selai kulit pisang kepok diperlukan bahan alami lain yang dapat meningkatkan rasa dari selai tersebut. Salah satu bahan alami yang dapat digunakan adalah pisang ambon, hal ini dikarenakan pisang ambon mempunyai rasa yang manis dan aroma yang harum.

Berdasarkan uraian diatas maka perlu dilakukan penelitian tentang pemanfaatan kulit pisang kepok menjadi selai dengan penambahan pisang ambon. Tujuan dari penelitian ini adalah untuk mengetahui pengaruh penambahan pisang ambon terhadap tingkat kesukaan selai, dan mengkarakterisasi selai yang dihasilkan meliputi kadar air dan daya oles selai. 


\section{METODE PENELITIAN}

\section{Bahan dan Alat}

Bahan yang digunakan adalah kulit pisang kepok matang, pisang ambon, air, gula pasir, asam sitrat dan roti tawar (roti agung ${ }^{\circledR}$ ). Sedangkan alat yang digunakan adalah pisau, piring plastik, sendok, talenan, blender, mangkok, wajan, panci, saringan, baskom, neraca analitik, neraca digital, oven, kompor gas, cawan porselin, penjepit cawan porselin, desikator, stopwatch, termometer, gelas ukur, kaca dan penggaris.

\section{Metode Penelitian}

Penelitian ini menggunakan 5 formulasi perbandingan antara bubur kulit pisang kepok dengan bubur pisang ambon yaitu sebagai berikut :

$\mathrm{P} 1=90 \%$ kulit pisang kepok : $10 \%$ pisang ambon

P2 $=80 \%$ kulit pisang kepok : $20 \%$ pisang ambon

P3 $=70 \%$ kulit pisang kepok : 30\% pisang ambon

$\mathrm{P} 4=60 \%$ kulit pisang kepok : 40\% pisang ambon

$\mathrm{P} 5=50 \%$ kulit pisang kepok : 50\% pisang ambon

Proses pembuatan selai adalah pertama dengan membuat bubur kulit pisang kepok, dimana kulit pisang dibersihkan, direbus selama 10 menit dan dikerok daging kulit pisang kemudian ditambahkan air dengan perbandingan 1:1, kemudian dihaluskan menggunakan blender selama 3 menit. Kedua, pembuatan bubur pisang ambon mengacu pada Herianto dkk. (2015), dimana pisang dibersihkan kemudian dihaluskan menggunakan blender. Ketiga, proses pembuatan selai mengacu pada Sutriono dkk. (2016) diawali dengan pencampuran bubur buah ke dalam panci, kemudian dimasak hingga setengah masak, kemudian ditambahkan gula dan asam sitrat, sedikit demi sedikit sambil diaduk agar homogen bersama bubur buah hingga terbentuk selai pada suhu $80^{\circ} \mathrm{C}$ selama 10 menit. Proses pemasakan dihentikan apabila adonan tidak jatuh saat diangkat menggunakan sendok (spoon test), selai didinginkan hingga suhu $40^{\circ} \mathrm{C}$, kemudian dimasukan ke dalam botol bersih. Penelitian ini dilakukan uji tingkat kesukaan (daya terima) yang dianalisis dengan uji ANOVA dan DMRT, sedangkan uji lainnya adalah uji kadar air yang mengacu pada Legowo dkk. (2007) dan daya oles selai mengacu pada Yuwono dkk. (1998). 


\section{HASIL DAN PEMBAHASAN}

\section{Tingkat Kesukaan (Daya Terima)}

Berdasarkan uji hedonik yang telah dilakukan terhadap semua perlakuan dengan pengujian kepada 20 orang panelis untuk mengetahui daya terima panelis diperoleh hasil nilai rata-rata yang dapat dilihat pada Gambar 1.

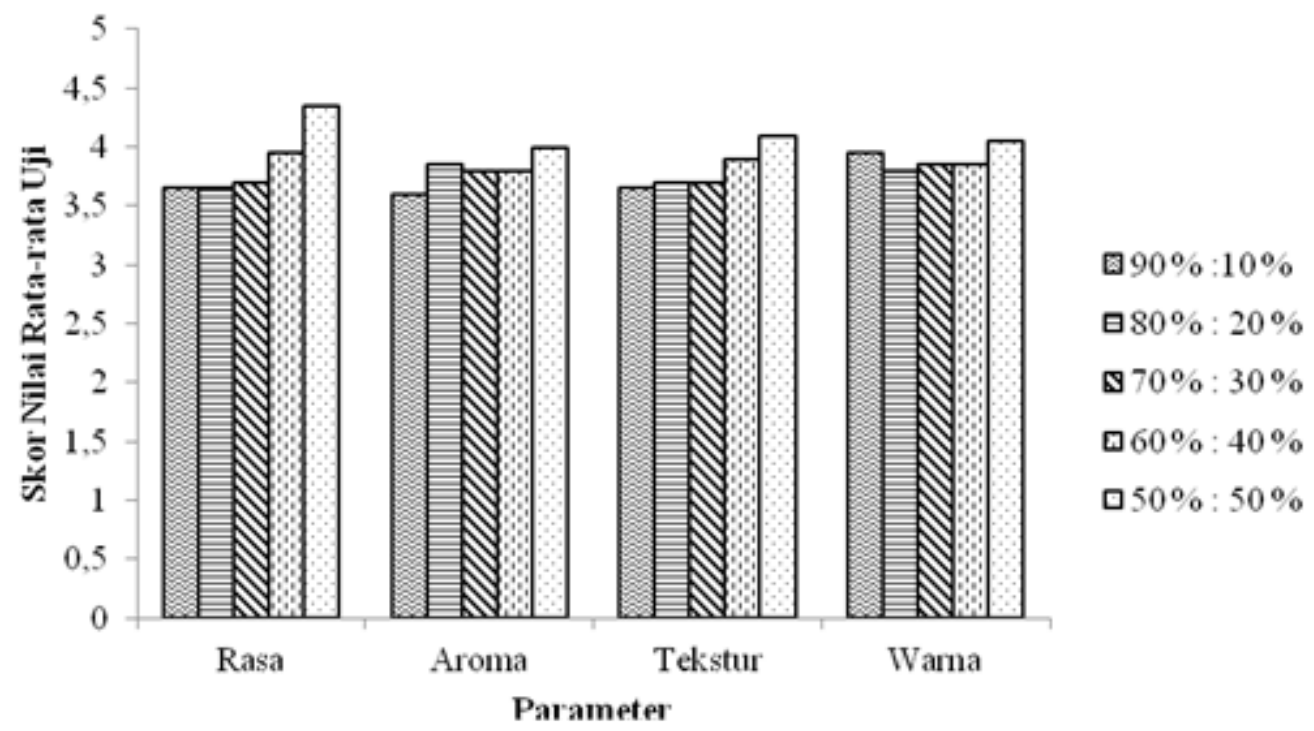

Gambar 1. Grafik uji tingkat kesukaan selai

a. Rasa

Rasa merupakan salah satu faktor utama yang menarik perhatian konsumen terhadap bahan makanan. Rasa terbentuk dari perpaduan komposisi bahan makanan yang digunakan dalam bahan makanan. Rasa banyak melibatkan panca indera lidah (Sutriono, 2016).

Berdasarkan hasil uji tingkat kesukaan selai pada parameter rasa, rata-rata yang diperoleh berkisar antara 3,65 - 4,35 (suka). Skor rata-rata tertinggi diperoleh pada perlakuan 50\% : 50\% bubur kulit pisang kepok dengan bubur pisang ambon dengan nilai rata-rata tingkat kesukaan (daya terima) adalah 4,35 (suka). Berdasarkan hasil uji ANOVA, diperoleh bahwa dari perlakuan formulasi bubur kulit pisang kepok dengan bubur pisang ambon berpengaruh nyata terhadap tingkat kesukaan (daya terima) panelis terhadap rasa selai, karena $\mathrm{F}$ hitung $>\mathrm{F}$ tabel $5 \%$, yang menunjukan bahwa semakin meningkat penambahan pisang ambon rasa selai yang dihasilkan semakin disukai oleh panelis, kemudian dilakukan uji lanjut duncan untuk melihat perbedaan dari tiap 
perlakuan formulasi terhadap tingkat kesukaan panelis pada rasa selai. Hasil dari uji DMRT dapat disimpulkan bahwa antara perlakuan P5 Berbeda nyata dengan perlakukan P1, P2, dan P3, tetapi berbeda tidak nyata pada perlakukan P4 terhadap tingkat kesukaan (daya terima) panelis terhadap rasa selai.

\section{b. Aroma}

Peranan aroma dalam makanan sangat penting, karena aroma turut menentukan daya terima konsumen terhadap makanan. Aroma atau bau terdeteksi ketika senyawa volatile masuk dan melewati saluran hidung dan diterima sistem olfaktori dan diteruskan ke otak. Aroma merupakan atribut sensori yang penting dan dapat dipengaruhi seseorang dalam menilai suatu produk makanan (Sutriono, 2016).

Berdasarkan hasil uji tingkat kesukaan selai pada parameter aroma rata-rata yang diperoleh berkisar antara 3,6-4 (suka). Skor rata- rata tertinggi diperoleh pada perlakuan 50\% : 50\% bubur kulit pisang kepok dengan bubur pisang ambon, dengan nilai rata-rata tingkat kesukaan (daya terima) adalah 4 (suka). Berdasarkan hasil uji ANOVA, dari perlakuan formulasi bubur kulit pisang kepok dengan bubur pisang ambon tidak berpengaruh nyata terhadap tingkat kesukaan (daya terima) panelis pada aroma selai, karena $\mathrm{F}$ hitung $<\mathrm{F}$ tabel $5 \%$ dan $1 \%$.

\section{c. Tekstur}

Tekstur merupakan sensasi tekanan yang dapat diamati dengan mulut (pada waktu digigit, dikunyah, ditelan) ataupun dengan perabaan dengan jari manis (Sutriono, 2016).

Berdasarkan hasil uji tingkat kesukaan selai pada parameter tekstur rata-rata yang diperoleh berkisar antara 3,65 - 4,1 (suka). Skor rata-rata tertinggi diperoleh pada perlakuan 50\% : 50\% bubur kulit pisang kepok dengan bubur pisang ambon, dengan nilai rata-rata tingkat kesukaan (daya terima) adalah 4,1 (suka). Berdasarkan hasil uji ANOVA, dari perlakuan formulasi bubur kulit pisang kepok dengan bubur pisang ambon tidak berpengaruh nyata terhadap tingkat kesukaan (daya terima) panelis pada tekstur selai, karena $\mathrm{F}$ hitung < $\mathrm{F}$ tabel 5\% dan $1 \%$.

d. Warna

Warna menjadi salah satu parameter yang sangat menentukan kesukaan konsumen terhadap suatu produk. Warna yang menarik bisa menimbulkan rasa suka 
terlebih dahulu sebelum konsumen tersebut mengkonsumsi makanan tersebut (Anam dkk., 2010).

Berdasarkan hasil uji tingkat kesukaan selai pada parameter warna, rata-rata yang diperoleh berkisar antara 3,8 - 4,05 (suka). Skor rata-rata tertinggi diperoleh pada perlakuan 50\% : 50\% bubur kulit pisang kepok dengan bubur pisang ambon, dengan nilai rata-rata tingkat kesukaan (daya terima) adalah 4,05 (suka). Berdasarkan hasil uji ANOVA, dari perlakuan formulasi bubur kulit pisang kepok dengan bubur pisang ambon tidak berpengaruh nyata terhadap tingkat kesukaan (daya terima) panelis pada warna selai, karena $\mathrm{F}$ hitung $<\mathrm{F}$ tabel $5 \%$ dan $1 \%$.

\section{Karakterisasi Selai}

Berdasarkan hasil uji karakterisasi selai meliputi kadar air dan daya oles terhadap semua perlakuan dengan 3 kali ulangan diperoleh hasil nilai rata-rata. Nilai rata-rata kadar air dan daya oles selai dapat dilihat pada Tabel 1.

Tabel 1. Hasil uji karakterisasi selai

\begin{tabular}{ccc}
\hline Perlakuan $(\boldsymbol{\%})$ & Kadar Air $(\boldsymbol{\%})$ & Daya Oles $(\mathbf{c m})$ \\
\hline $90: 10$ & 35,06 & 10,3 \\
$80: 20$ & 34,22 & 10,7 \\
$70: 30$ & 33,02 & 11,6 \\
$60: 40$ & 31,29 & 10,7 \\
$50: 50$ & 29,71 & 9 \\
\hline
\end{tabular}

a. Kadar Air

Kadar air ialah salah satu karakteristik yang sangat penting pada bahan pangan, karena air dapat mempengaruhi penampakan, tekstur, dan cita rasa pada bahan pangan. Kadar air dalam bahan pangan ikut menentukan kesegaran dan daya awet bahan pangan tersebut (Sutriono, 2016).

Berdasarkan hasil uji kadar air dari semua perlakuan selai, kadar air berkisar antara $29,71-35,06 \%$. Standar mutu kadar air selai menurut SNI-01-3746-2008 adalah 35\%, sehingga kadar air pada selai yang dihasilkan memenuhi standar mutu selai. Kadar air selai dapat dipengaruhi oleh kadar air bahan serta suhu dan waktu pemasakan. Pada penelitian ini pembuatan bubur kulit pisang kepok mengalami proses perebusan dan penambahan air saat penghalusan, sehingga kadar air kulit pisang meningkat, sedangkan untuk pembuatan bubur pisang ambon tanpa penambahan air, sehingga pada suhu dan 
waktu pemasakan yang sama formulasi selai dengan bubur kulit pisang kepok yang tinggi mempunyai kadar air lebih tinggi.

Faktor lain yang juga mempengaruhi kadar air adalah penambahan gula pasir (sukrosa), jumlah penambahan gula pada penelitian ini mempunyai takaran yang sama. Sukrosa merupakan senyawa yang bersifat higrokopis karena mampu mengikat air bebas (Fahrizal dkk., 2014).

\section{b. Daya Oles}

Daya oles adalah kemampuan selai untuk dioleskan secara merata pada roti. Selai dengan daya oles yang baik dapat dioleskan di permukaan roti dengan mudah menghasilkan olesan yang merata (Agustina dkk., 2016).

Berdasarkan uji daya oles dari semua perlakuan selai yang dihasilkan mempunyai daya oles yang mudah untuk dioleskan, panjang rata-rata daya oles semua perlakuan berkisar antara $9-11,6 \mathrm{~cm}$. Menurut Wirawan dkk. (2008) Daya oles semakin tinggi menunjukkan bahwa selai makin mudah untuk dioles. Daya oles selai erat kaitannya dengan tekstur dan kadar air. Menurut Sundari, dkk (2010) selai yang mempunyai kadar air terlalu tinggi (encer) ataupun terlalu rendah (keras) dapat mempengaruhi daya oles. Selai dari semua perlakuan mempunyai daya oles yang baik dilihat dari tekstur yang tidak terlalu encer dan tidak terlalu keras.

\section{KESIMPULAN}

Penambahan pisang ambon berpengaruh nyata terhadap tingkat kesukaan panelis pada rasa selai dengan formulasi selai terbaik berdasarkan tingkat kesukaan (daya terima panelis) diperoleh pada perlakuan 50\% : 50\% bubur kulit pisang kepok dengan bubur pisang ambon. Karakterisasi selai yang dihasilkan dari semua perlakuan mempunyai kadar air berkisar antara 29,71-35,06\% dan daya oles berkisar antara $9-11,6 \mathrm{~cm}$.

\section{UCAPAN TERIMA KASIH}

Ucapan terima kasih disampaikan kepada dosen, staf, dan laboran Program Studi Teknologi Industri Pertanian Politeknik Negeri Tanah Laut atas dukungannya dalam pelaksanaan penelitian ini hingga berjalan dengan lancar. 


\section{DAFTAR PUSTAKA}

Agustina, W.W. dan Handayani, M.N., 2016. Pengaruh Penambahan Wortel (Daucus carota) Terhadap Karakteristik Sensori dan Fisiko Kimia Selai Buah Naga Merah (Hyloreceus polyhiruz). Fortech 1 (1).

Anam, C. dan Handajani, S., 2010. Mi Kering Waluh (cucurbita moschata) dengan Antioksidan dan Pewarna Alami. Jurnal Caraka Tani XXV No.1.

Badan Pusat Statistik dan Kementerian Pertanian Kabupaten Tanah Laut Kalimantan Selatan., 2017. Laporan Tanaman Buah-buahan dan Sayuran Tahunan. Triwulan 1.

Badan Standardisasi Nasional., 2008. Selai Buah SNI-01-3746-2008. Jakarta. http://sisni.bsn.go.id/index.php?/sni_main/sni/detail_sni/7708 diakses pada hari Kamis tanggal 27 April 2017, pada pukul 15.26 WITA.

Fahrizal. dan Fadhil, R., 2014. Kajian Fisiko Kimia dan Daya Terima Organoleptik Selai Nenas yang Menggunakan Pektin dari Limbah Kulit Kakao. Jurnal Teknologi dan Industri Pertanian Indonesia Vol. (6) No.3.

Herianto, A., Hamzah F. dan Yusmarini., 2015. Studi Pemanfaatan Buah Pisang Mas (Musa acuminata) dan Buah Naga Merah (Hylocereus polyrhizus) dalam Pembuatan Selai. Jom FAPERTA Vol. 2 No. 2.

Legowo, A.M., Nurwantoro. dan Sutaryo., 2007. Buku Ajar Analisis Pangan. Semarang: Universitas Diponegoro.

Sundari, D. dan Komari., 2010. Formulasi Selai Pisang Raja Bulu dengan Tempe dan Daya Simpannya (formulation the jam mixture of 'raja bulu' banana with tempe and durability). PGM 2010, 33(1): 93-101.

Sutriono, Y. dan Pato, U., 2016. Pemanfaatan Buah Terung Belanda dan Pisang Kepok dalam Pembuatan Selai. Jurnal Faperta Vol. 3 No. 2.

Wirawan. dan Mushollaeni, W., 2008. Optimasi Lama Blanching Pengolahan Selai Kacang Tanah Metode Regresi Kuadratik. Jurnal Buana Sains Vol 8 No 1.

Yuwono, S.S. dan Tri, S., 1998. Pengujian Fisik Pangan. Malang: Universitas Brawijaya.GoogleCendekia.https://scholar.google.co.id/citations?user=SYvvD5YA AAAJ\&hl=id diakses pada tanggal 02 Mei 2017, pukul 15.37 WITA. 